\title{
The value of civic life
}

Since the last arq was printed, the world has been convulsed by the rapid global spread of the COVID-19 virus. Numerous countries - the British domicile of this journal included - have experienced lockdown, where individuals and families are asked to stay at home to reduce the spread of the disease. The construction industry has largely ceased work, and numerous architectural practices have placed their staff on furlough.

The lived experience of lockdown has been simultaneously localising and globalising. Most people's immediate horizons have been redrawn around the limits of their domestic space. Yet communications technologies - Zoom, Skype, FaceTime, Teams - mean that it's as easy to work with, and socialise with, those on the other side of the globe as with those in the same office or neighbourhood. The loss of civic space - namely the streets and rooms of the city, and their associated theatres, music venues, community centres, libraries, museums, galleries, restaurants, bars, pools, gyms, stadia, and sports fields - has been experienced deeply by some, for whom their closure has invoked a kind of mourning. Lockdown has thrown into sharp relief the value and the values of civic space. It has also highlighted their importance to the reclamation of whatever new normal will follow.

The papers that bookend this issue of arq - by Daniel Mallo, Armelle Tardiveau, and Rorie Parsons (pp. 100-116), and by Ruth Morrow, Peter Mutschler, and Timothy Waddell (pp. 183-203) - account for practice-led and practice-based research that celebrates and extends the co-production of civic life and space. Both illustrate, in different contexts, how architects can enable citizens to claim, inhabit, and rethink civic space, and make it more social, vital, and meaningful. These are important lessons at any time, though they resonate particularly strongly at this moment when the significance of living together, and being together in the city, has been reinforced.

We don't know yet what the so-called post-COVID-19 world will be like. Environmentally, many people have become accustomed to travelling less - to cycling rather than driving, to Zoom-ing rather than flying - and the lessons learnt should contribute to addressing the current climate emergency. The economy, not least in architecture and construction, looks set to remain fragile for some time and it seems that architectural practice will enter one of its periodic states of contraction and introspection. The economic shock, societally and individually, may be substantial and prevailing inequalities look set to be exacerbated. While the civic spaces of the city may reopen gradually, we have been reminded of their value. As authors in this issue of arq illustrate, we can learn how to celebrate and co-create those civic spaces afresh as-and-when we we're able to enjoy them fully once more. 